\title{
Pengaruh Profitabilitas ,Ukuran Perusahaan Terhadap Leverage Implikasi Terhadap Nilai Perusahaan Cosmetics and Household yang terdaftar di Bursa Efek Indonesia
}

\author{
A. Kadim ${ }^{1} \&$ Nardi Sunardi ${ }^{2}$ \\ 1) dosen Universitas Persada Indonesia YAl, email : sak kadim@yahoo.com \\ ${ }^{2)}$ dosen Universitas Pamulang, email : dosen01030@unpam.ac.id
}

\section{ARTICLES INFORMATION}

ABSTRACT

\section{JURNAL SEKURITAS \\ (Saham, Ekonomi, \\ Keuangan dan Investasi) \\ Vol.3, No.1, September 2019 \\ Halaman : 22 - 32 \\ ๑ ( LPPM \& Prodi Manajemen \\ UNVERSITAS PAMULANG \\ ISSN (online) : 2581-2777 ISSN (print) : 2581-2696}

\section{Keyword:}

Profitabilitas, Ukuran

Perusahaan, Leverage

dan Nilai Perusahaan".

\section{JEL Classification : \\ C33, G21, G24, N15, N25 \\ Contact Author: \\ PRODI MANAJEMEN UNPAM \\ JL.Surya Kencana No.1 Pamulang \\ Tangerang Selatan-Banten \\ Telp. (021) 7412586, Fax (021) 7412491 Email: \\ jumalfinance.unpam@gmail.com}

sekuritas@unpam.ac.id

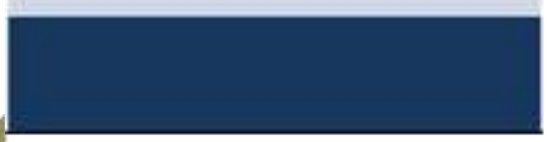

"Tujuan dari penelitian secara empiris untuk membuktikan adanya Pengaruh Profitabilitas ,Ukuran Perusahaan Terhadap Leverage Implikasi Terhadap Nilai Perusahaan Cosmetics and Household yang terdaftar di Bursa Efek Indonesia baik secara parsial maupun simultan. Peneliti menggunakan sampel 5 emiten dengan kapitalisasi pasar terbesar dari Index Saham LQ45 Bursa Efek Indonesia. mulai tahun 2011-2017. Penelitian menggunakan sampel 5 perusahaan cosmetics and household yang diambil dengan menggunakan teknik purposive sampling" "Metode analisis data yang dilakukan dalam penelitian ini menggunakan metode analisis regresi data panel. Untuk menentukan salah satu dari tiga pendekatan regresi panel yang akan digunakan yaitu ordinary least square" (OLS), berpengaruh negatif atau positif signifikan terhadap Leverage, Ukuran Perusahaan berpengaruh positif atau signifikan terhadap Leverage, Profitabilitas dan Ukuran Perusahaan berpengaruh positif atau signifikan terhadap Leverage. Profitabilitas berpengaruh tidak signifikan terhadap Nilai Perusahaan. Ukuran Perusahaan berpengaruh negatif dan positif tidak signifikan terhadap Nilai Perusahaan, Leverage berpengaruh tidak signifikan terhadap Nilai Perusahaan. Profitabilitas, Ukuran Perusahaan, Leverage berpengaruh tidak signifikan terhadap Nilai Perusahaan".

"The purpose of empirical research is to prove the effect of profitability, company size on the leverage implications for the value of cosmetics and household companies listed on the Indonesia Stock Exchange either partially or simultaneously. Researchers used a sample of 5 listed companies with the largest market capitalization from the LQ45 Stock Index of the Indonesia Stock Exchange. starting in 2011-2017. The study used a sample of 5 cosmetics and household companies taken by using purposive sampling technique. The data analysis method used in this study uses panel data regression analysis method. To determine one of the three panel regression approaches that will be used, namely ordinary least square (OLS),) has a significant negative or positive effect on Leverage, firm Size has a positive or significant effect on Leverage, Profitability and firm Size has a positive or significant effect on Leverage. Profitability has no significant effect on firm Value. firm size does not have a significant negative and positive effect on firm value, leverage does not have a significant effect on firm value. Profitability, firm Size, Leverage has no significant effect on firm Value ". 


\section{A. PENDAHULUAN}

\section{Latar Belakang}

"Industri manufaktur di Indonesia mengalami pertumbuhan selama beberapa waktu terakhir setelah sempat mengalami penurunan sejak krisis finansial Asia tahun 1996. Pertumbuhan ini dipicu oleh tingginya permintaan domestik dan cepatnya pertumbuhan investasi asing" (Syafputri, 2012), "(Dalam skripsi analisis pengaruh profitabilitas,likuiditas,pertumbuhan perusahaan dan ukuran perusahaan terhadap kebijakan hutang,2013). Perusahaan-perusahaan yang telah go public adalah perusahaan yang mencatat sahamnya dibursa efek. Perusahaan tersebut memiliki struktur kepemilikan modal yang berbeda dengan perusahaan yang tidak mencatatkan sahamnya di bursa efek. Perbedaan yang mendasar adalah bahwa perusahaan yang telah go public memiliki pemegang saham dari kalangan publik. Perusahaan mau melakukan go public karena membutuhkan dana untuk kegiatan operasi ataupun pendanaan lainnya" (Brigham \& Houston, 2013)

Perusahaan merupakan suatu organisasi yang memiliki visi dan misi yang menjalankan kegiatan perusahaan dengan tujuan untuk selalu mengembangkan apa yang ingin diwujudkan dan dicapai. Berkembangnya perusahaan sangat berpengaruh pada setiap individu atau sumber daya manusia, organisasinya. Penelitian ini mempunyai tujuan untuk mengetahui Pengaruh profitabilitas ukuran perusahaan terhadap leverage implikasi nilai perusahaan. Data sekunder dari penelitian ini berupa laporan keuangan perusahaan cosmetics and household yang terdaftar di Bursa Efek Indonesia (www.idx.com).

Dalam menentukan nilai perusahaan, "ada beberapa faktor yang dipertimbangkan oleh perusahaan pada umumnya antara lain profitabilitas, ukuran perusahaan,dan laverage. Profitabilitas adalah laba yang diperoleh perusahaan pada periode tertentu. Perusahaan dengan tingkat profitabilitas yang sangat tinggi biasanya menggunakan hutang dalam jumlah yang relatif sedikit. Karena tingkat pengembalian yang tinggi memungkinkan perusahaan tersebut melakukan sebagaian besar pendanaannya melaui dana yang dihasilkan secara internal" (Keown AJ, 2010)). Hal ini sesuai dengan packing order theory yang menetapkan suatu urutan pendanaan dimana para manajer pertama kali akan memilih untuk menggunakan laba ditahan, hutang dan penerbitan saham sebagai pilihan terakhir (Mamduh, 2004). "Dalam penelitian yang dilakukan oleh Santika dan Kusuma (2002) pengaruh profitabilitas sebagai indikator kinerja perusahaan berpengaruh positif terhadap perusahaan. Karena dengan meningkatnya kinerja perusahaan akan meningkatkan ROA dan ROE yang merupakan contoh proksi dan rasio profitabilitas.

Ukuran perusahaan (Firm Size) merupakan suatu indikator yang menunjukkan kekuatan finansial perusahaan. Ukuran perusahaan dianggap mampu mempengaruhi nilai perusahaan, karena semakin besar ukuran atau skala perusahaan maka akan semakin mudah pula perusahaan memperoleh sumber pendanaan baik yang bersifat internal maupun eksternal." (Sunardi L. H., 2017) "menunjukkan bahwa ukuran perusahaan berpengaruh positif terhadap nilai perusahaan".

Struktur modal adalah "proporsi pendanaan dengan hutang (Debt Financing) perusahaan, yaitu rasio leverage (pengungkit) perusahaan. Dengan demikian, hutang adalah unsur dari struktur modal perusahaan. Struktur modal merupakan kunci perbaikan produktivitas dan kinerja perusahaan. Teori struktur modal menjelaskan bahwa kebijakan pendanaan (Financial Policy) perusahaan dalam menentukan struktur modal (bauran antara hutang dan ekuitas) bertujuan untuk mengoptimalkan nilai perusahaan (Value of the Firm). Struktur modal yang optimal suatu perusahaan adalah kombinasi dari utang dan ekuitas (sumber eksternal) yang memaksimumkan harga saham perusahaan. Pada saat 
tertentu, manajemen perusahaan menetapkan struktur modal yang ditargetkan, yang mungkin merupakan struktur yang optimal, meskipun target tersebut dapat berubah dari waktu ke waktu. Sejumlah faktor mempengaruhi keputusan mengenai struktur modal perusahaan, seperti stabilitas penjualan, struktur aktiva, leverage operasi, peluang pertumbuhan, tingkat profitabilitas, pajak penghasilan, tindakan manajemen dan sebagainya. Faktor-faktor lain yang mempengaruhi struktur modal perusahaan adalah ukuran perusahaan, perusahaan yang lebih besar pada umumnya lebih mudah memperoleh pinjaman dibandingkan dengan perusahaan kecil. Oleh sebab itu dengan memperoleh pinjaman perusahaan dapat berkembang lebih baik lagi" (Sunardi N. 2017).

Berdasarkan konsep diatas, maka dalam penelitian ini variabel Pengaruh profitabilitas (ROA), ukuran perusahaan (SIZE) terhadap leverage (DER) implikasi terhadap nilai perusahaan (PBV) akan dipergunakan sebagai variabel-variabel bebas yang berpengaruh terhadap nilai perusahaan, dimana nilai perusahaan diproksikan dalam Price to Book Value (PBV).

Hasil penelitian terdahulu tentang pengaruh profitabilitas terhadap nilai perusahaan yang dilakukan oleh Susanti dan Santoso (2011) dengan judul yaitu "Pengaruh Profitabilitas Terhadap Nilai Perusahaan dengan pengungkapan corporate social responsibility sebagian variabel moderasi menghasilkan temuan bahwa tingkat profitabilitas perusahaan berpengaruh positif terhadap nilai perusahaan. Variabel CSR sebagai pemoderasi mampu mempengaruhi hubungan antara profitabilitas terhadap nilai perusahaan secara positif".

Berdasarkan hasil penelitian terdahulu "menyatakan bahwa pengaruh profitabilitas terhadap nilai perusahaan tidaklah konsisten. Hal ini dibuktikan oleh penelitian yang dikemukakan oleh Suranata dan Pranata (2004) dan Kaaro (2002) dalam Yunlasih dan Wirakusuma bahwa profitabilitas berpengaruh negatif terhadap nilai perusahaan. Dari hasil penelitian terdahulu diatas menjelaskan bahwa dubungan variabel dependen berpengaruh terhadap Price to Book Value. Dari hasil penelitian terdahulu terdapat beberapa variabel yang berpengaruh terhadap Price to Book Value (PBV) masih menunjukkan hasil yang berbeda bahkan bertentangan antara hasil penelitian yang satu dengan yang lainnnya. Dari penemuan tersebut diasumsikan bahwa ada faktor lain yang ikut menginteraksi". Hal inilah yang akan diangkat menjadi research gap dalam penelitian ini.

Mengingat pentingnya profitabilitas,ukuran perusahaan, leverage implikasi terhadap nilai perusahaan, disini penulis akan meneliti sebuah laporan perusahaan cosmetics and household yang bergerak dibidang manufaktur. Maka dari itu penulis mengangkat judul Pengaruh Profitabilitas ,Ukuran Perusahaan Terhadap Leverage Implikasi Terhadap Nilai Perusahaan Cosmetics and Household yang terdaftar di Bursa Efek Indonesia.

\section{Perumusan Masalah}

Perumusan masalah sebagai berikut :

1. Bagaimana pengaruh profitabilitas yang diproksikan dengan return on asset (ROA) terhadap leverage yang diproksikan dengan Debt Equity Rasio (DER) ?

2. Bagaimana pengaruh ukuran perusahaan yang diproksikan dengan firm size (SIZE) terhadap leverage yang diproksikan dengan Debt Equity Rasio (DER) ?

3. Bagaimana pengaruh profitabilitas yang diproksikan dengan Return On Assets $(R O A)$ terhadap ukuran perusahaan yang diproksikan dengan Firm Size (SIZE) ?

4. Bagaimana pengaruh profitabilitas, dan ukuran perusahaan, terhadap leverage yang diproksikan dengan Debt Equity Rasio (DER)?

5. Bagaimana pengaruh profitabilitas yang diproksikan dengan Return On Assets $(R O A)$ terhadap nilai perusahaan yang diproksikan dengan Price to Book Value (PBV) ?

6. Bagaimana pengaruh ukuran perusahaan yang diproksikan dengan Firm Size (SIZE) terhadap nilai perusahaan yang diproksikan dengan Price to Book Value (PBV) ? 
7. Bagaimana pengaruh profitabilitas, ukuran perusahaan, dan leverage terhadap nilai perusahaan yang diproksikan dengan Price to Book Value (PBV) ?

8. Bagaimana pengaruh leverage yang diproksikan dengan Debt Equity Rasio (DER) terhadap nilai perusahaan yang diproksikan dengan Price to Book Value (PBV) ?

\section{B. KAJIAN LITERATUR}

\section{Nilai Perusahaan (PBV)}

Nilai perusahaan "merupakan harga yang bersedia dibayar oleh calon pembeli apabila perusahaan tersebut dijual. Berbagai kebijakan diambil oleh manajemen dalam upaya meningkatkan nilai perusahaan melalui peningkatan kemakmuran pemilik dan pemegang saham tercermin pada harga saham (Brigham, 2001). Samuel (2000) menjelaskan bahwa enterprise value (EV) atau dikenal juga sebagai firm value (nilai perusahaan) ,Merupakan konsep penting bagi investor, karena merupakan indikator bagi pasar menilai perusahaan secara keseluruhan" (Sunardi N.) , Sedangkan, Untung Wahyudi dan Hartini (2005) menyebutkan bahwa" nilai perusahaan merupakan harga yang bersedia dibayar oleh calon pembeli andai perusahaan tersebut dijual".

"Nilai perusahaan dibentuk melalui indikator nilai pasar saham sangat dipengaruhi ole peluang-peluang investasi. Adanya peluang investasi dapa memberikan sinyal positif tentang pertumbuhan perusahaan di masa yang akan datan sehingga dapat meningkatkan nila perusahaan.Nilai perusahaan merupakan persepsi investor terhadap tingkat keberhasilan perusahaan yang sering dikaitkan dengan harga saham" (Sujoko dan Soebiantoro ,2007). "Harga saham yang tinggi membuat nilai perusahaan juga tinggi. Nilai perusahaan yang tinggi akan membuat pasar percaya tidak hanya pada kinerja perusahaan saat ini namun juga pada prospek perusahaan di masa depan". Menurut Suharli (2007), "dalam penilaian perusahaan mengandung unsur proyeksi, asuransi, perkiraan dan judgement. Nilai dari perusahaan" bergantung tidak hanya pada kemapuan menghasilkan arus kas, tetapi juga bergantung pada karakteristik operasional dan keuangan dari perusahaan yang diambil alih".

\section{Laverage (DER)}

Leverage merupakan "perimbangan antara penggunaan modal sendiri dengan penggunaan hutang, yang berarti berapa besar modal sendiri dan berapa besar hutang yang akan digunakan, sehingga dapat dijadikan bahan pertimbangan dalam mengambil kebijakan hutang. Tujuan penelitian ini adalah untuk mengetahui dan menganalisis pengaruh antara struktur aktiva, profitabilitas, ukuran perusahaan terhadap nilai perusahaan pada perusahaan cosmetics and household yang terdaftar pada Bursa Efek Indonesia (BEI) periode tahun 2011 sampai dengan 2017".

Menurut Brigham dan Houston (2007), "struktur modal atau leverage yang optimum adalah struktur yang memaksimalkan harga dari saham perusahaan. Oleh karena itu, manajemen dalam menetapkan leverage tidak bersifat kaku tetapi disesuaikan dengan keadaaan perusahaan. Dengan demikian, tujuan pihak manajemen untuk memaksimumkan kemakmuran pemegang saham dapat tercapai”.

Leverage ada dua "macam, leverage operasi dan leverage keuangan. Leverage operasi disebabkan karena sebagian biaya usaha bersifat tetap, sedangkan peningkatan volume operasi yang terjadi cukup besar. Akibatnya laba akan naik atau turun lebih tajam dibandingkan dengan perubahan volume operasi. Demikian pula, leverage keuangan akan terjadi bila struktur keuangan suatu perusahaan mengandung utang (kewajiban)" (Sunardi \& Permana, 2019)

\section{Profitabilitas (ROA)}

"Rasio profitabilitas merupakan rasio untuk menilai kemampuan perusahaan dalam mencari keuntungan. Rasio ini juga memberikan ukuran tingkat efektivas manajemen suatu 
perusahaan. Hal ini ditunjukkan oleh laba yang dihasilkan dari penjualan dan pendapatan investasi. Intinya adalah penggunaan rasio ini menunjukkan efisiensi perusahaan. Penggunaan rasio profitabilitas dapat dilakukan dengan menggunakan perbandingan antara berbagai komponen yang ada di laporan keuangan, terutama laporan keuangan neraca dan periode operasi. Tujuannya adalah agar terlihat perkembangan perusahaan dalam rentang waktu tertentu, baik penurunan atau kenaikan, sekaligus mencari penyebab perubahan tersebut". (Sunardi N. 2018)

(Kasmir, 2014),"Tujuan penggunaan rasio profitabilitas bagi perusahaan, maupun bagi pihak luar perusahaan ,yaitu :

1. Untuk mengukur atau menghitung laba yang diperoleh perusahaan dalam satu periode tertentu.

2. Untuk menilai posisi laba perusahaan tahun sebelimnya dengan tahun sekarang.

3. Untuk menilai perkembangan laba dari waktu ke waktu.

4. Untuk menilai besarnya laba bersih sesudah pajak dengan modal sendiri.

5. Untuk mengukur produktivas seluruh dana perusahaan yang digunakan baik modal pinjaman maupun modal sendiri.

6. Untuk mengukur produktivitas dari seluruh dana seluruh dana perusahaan yang digunakan baik modal sendiri".

Rasio profitabilitas merupakan "rasio yang mengukur kemampuan perusahaan dalam menghasilkan laba (profitabilitas) pada tingkat penjualan, aktiva, dan modal. Ada tiga rasio yang dapat digunakan dalam rasio profitabilitas, yaitu rasio net profit margin (NPM), return on asset $(R O A)$, dan return on equity (ROE). net profit margin mengukur sejauh mana perusahaan menghasilkan laba bersih pada tingkat penjualan tertentu. Rasio NPM yang rendah dapat menunjukkan ketidakefisienan manajemen. ROA menunjukkan seberapa besar kemampuan perusahaan menghasilkan laba dengan memanfaatkan aktiva yang dimilikinya. Sedangkan ROE menggambarkan tingkat return yang dihasilkan perusahaan bagi pemegang sahamnya. Profitabilitas merupakan variabel independen penting yang mempunyai pengaruh pada struktur modal. Semakin tinggi profit suatu perusahaan maka akan semakin menurun hutangnya karena semakin banyak dana internal yang tersedia untuk mendanai investasinya" (Brigham dan Houston, 2011).

\section{Ukuran Perusahaan (size)}

Ukuran perusahaan adalah "rata-rata total penjualan bersih untuk tahun yang bersangkutan sampai beberapa tahun. Dalam hal ini penjualan lebih besar dari pada biaya variabel dan biaya tetap, maka akan diperoleh jumlah pendapatan sebelum pajak. Sebaliknya jika penjulan lebih kecil dari pada biaya variabel dan biaya tetap maka perusahaan akan menderita kerugian" (Brighman and Houston 2001). "Keadaan yang dikehendaki oleh perusahaan adalah perolehan laba bersih sesudah pajak karena bersifat menambah modal sendiri. Laba operasi ini dapat diperoleh jika jumlah penjualan lebih besar dari pada jumlah biaya variabel dan biaya tetap. Agar laba bersih yang diperoleh memiliki jumlah yang dikehendaki maka pihak manajemen akan melakukan perencanaan penjualan yang dikehendaki maka pihak manajemen akan melakukan perencanaan penjulan secara seksama, serta dilakukan pengendalian yangtepat, guna mencapai jumlah penjualan yang dikehendaki. Manfaat pengendalian manajemen adalah untuk menjamin bahwa organisasi telah melaksanakan strategi usahanya dengan efektif dan efisien. Dalam aspek financial, penjualan dapat dilihat dari sisi perencanaan dan sisi realisasi yang diukur dalam satuan rupiah. Dalam sisi perencanaan, penjualan direfleksikan dalam bentuk target yang diharapkan dapat direalisir oleh perusahaan. Perusahaan dengan ukuran yang lebih besar memiliki akses yang lebih besar untuk mendapatkan sumber pendanaan dari berbagai sumber, sehingga untuk memperoleh pinjaman dari kreditur pun akan lebih mudah karena perusahaan dengan ukuran besar untuk memenangkan persaingan atau bertahan dalam industri. Pada sisi lain, perusahaan dengan skala kecil lebih fleksibel dalam menghadapi ketidakpastian, karena perusahaan kecil lebih cepat bereaksi terhadap 
perubahan yang mendadak. Oleh karena itu, memungkinkan perusahaan besar tingkat leveragenya akan lebih besar dari perusahaan yang berukuran kecil" (Sunardi L. H., 2017)..

\section{METODOLOGI PENELITIAN}

Penelitian ini "menggunakan data sekunder, yaitu data yang diperoleh secara tidak langsung dari perusahaan yang dijadikan objek penelitian. Data sekunder didapat berupa laporan keuangan perusahaan tahunan yang terdaftar dan di publikasikan di Bursa Efek Indonesia" (Bambang Juanda, 2012)

Jenis penelitian "yang digunakan dalam penelitian ini yaitu penelitian eksplanatori. Variabel yang digunakan dalam penelitian ini yaitu nilai perusahaan, variabel terikat (dependent variable) kebijakan hutang, profitabilitas, ukuran perusahaan, Penelitian ini mengambil studi kasus pada perusahaan cosmetics and household Indonesia yang telah terdaftar di Bursa Efek Indonesia (BEl) selama lima tahun terakhir yaitu mulai tahun 20112017. Data sekunder diperoleh dari publikasi website resmi Bursa Efek Indonesia (BEI) yaitu www.idx.co.id. Penelitian menggunakan sampel 5 perusahaan cosmetics and household yang diambil dengan menggunakan teknik purposive sampling" (Sugiyono., 2012).

Metode analisis data "yang dilakukan dalam penelitian ini menggunakan metode analisis regresi data panel. Untuk menentukan salah satu dari tiga pendekatan regresi panel yang akan digunakan yaitu ordinary least square (OLS) atau common effect model, fixed effect model, random effect model. maka dilakukan Chow test dan Hausman test dengan teknik estimasi path analysis" (Sunardi N. , 2018) "Untuk mengolah data sekunder yang didapat, peneliti mengunakan program aplikasi bantuan software statistik diantaranya MS.Exel 2010 meliputi pembuatan tabel dan grafik untuk analisis deskriptif. Sedangkan kegiatan pengolahan data dengan EVIEWS versi 9 digunakan untuk membantu dalam menganalisis data yang digunakan dalam melakukan pengujian signifikasi analisis regresi linier berganda data panel"..

\section{Sampel Penelitian}

\begin{tabular}{lll}
\hline No & Kode Perusahaan & Nama Perusahaan \\
\hline 1 & ADES & PT.Akasha Wira International Tbk \\
2 & MBTO & PT.Martina Berto Tbk \\
3 & TCID & PT.Mandon Indonesia Tbk \\
4 & UNVR & PT.Unilever Indonesia \\
5 & MRAT & PT.Mustika Ratu Tbk \\
\hline
\end{tabular}

Sumber : Indonesian Capital Market Directory periode Tahun 2011-2015.

\section{HASIL DAN PEMBAHASAN}

Pengaruh profitabilitas, ukuran perusahaan terhadap variabel dependen kebijakan hutang / leverage yang diproksikan dengan debt to equity (DER)

Pengujian Common Effect Model, Fixed Effect Model dan Random Effect Model.

Setelah dilakukan pengujian pada ketiga model di atas, perbandingan pengujiannya disajikan sebagai berikut:

Hasil pengujian model 


\begin{tabular}{llll}
\hline No. & Model & \multicolumn{1}{c}{ Pengujian } & Hasil \\
\hline 1. & Chow Test & Common Effect vs Fixed Effect & Fixed Effect \\
2. & Hausmant Test & Random Effect vs Fixed Effect & Fixed Effect \\
3. & LM Test & Common Effect vs Random Effect & Random Effect \\
\hline
\end{tabular}

Berdasarkan pengujian diatas, maka model yang dipilih untuk mengestimasi model regresi data panel.dalam penelitian ini adalah Fixed Effect Model

Berikut ini peneliti menyajikan Fixed Effect Model

\begin{tabular}{lllll}
\hline Variable & Coefficient & Std. Error & t-Statistic & Prob. \\
\hline ROA & 0.355621 & 1.086223 & -0.327392 & 0.0471 \\
SIZE & -0.030624 & 0.070368 & -0.435201 & 0.6686 \\
C & 1.324555 & 1.596679 & 0.829569 & 0.4176 \\
\hline Effects Specification & & & \\
\hline Cross-section fixed (dummy variables) & & & \\
\hline R-squared & 0.916724 & Mean dependent var & 0.692800 \\
Adjusted R-squared & 0.888965 & S.D. dependent var & 0.762958 \\
S.E. of regression & 0.254232 & Akaike info criterion & 0.330359 \\
Sum squared resid & 1.163413 & Schwarz criterion & 0.671644 \\
Log likelihood & 2.870514 & \multicolumn{2}{c}{ Hannan-Quinn criter. } & 0.425017 \\
F-statistic & 33.02463 & \multicolumn{2}{c}{ Durbin-Watson stat } & 0.987894 \\
Prob(F-statistic) & & \multicolumn{2}{c}{0.000000} & \\
\hline
\end{tabular}

Kesimpulan hasil

\begin{tabular}{lclll}
\hline Model & $\begin{array}{l}\text { Adjusted R- } \\
\text { squared }\end{array}$ & \multicolumn{2}{l}{$\begin{array}{l}\text { Prob.(F-statistic) } \\
\mathbf{\alpha - 0 , 0 5}\end{array}$} & Probabilitas $\mathbf{\alpha - 0 , 0 5}$ \\
\hline Fixed Effect & 0.916724 & 0.0000 & ROA & negatif Signifikan \\
& & & SIZE & Positif tidak Signifikan \\
\hline
\end{tabular}

Uji $\mathrm{F}$ menunjukan "bahwa seluruh variabel bebas yang digunakan penelitian ini secara bersama sama mepengaruhi nilai perusahaan (Price Book Value) yang diproksikan dengan PBV perusahaan secara signifikan dengan tingkat keyakinan 100 persen. Sementara pengujian goodnes of fit, menunjukan kefiseien dereminasi $R^{2}=1.00000$ yang berarti seluruh variable bebas profitabilitas, ukuran perusahaan,kebijakan hutang/leverage dapat menjelaskan kepemilikan nilai perusahaan (Price Book Value) 100 persen, sementara sisanya 0 persen dijelaskan oleh faktor-faktor lain yang tidak diikutsertaskan dalam model ini. Sementara nilai koefisien determinasi yang disesuaikan $R^{2}=1,0000$ yang berarti setelah mempertimbangkan derajat kebebasan (degree of freedom), seluruh variabel bebas yang digunakan dalam penelitian ini mampu menjelaskan variasi yang terjadi dalam nilai perusahaan (Price Book Value) perusahaan cosmetics and household yang tercatat di IDX (Indonesia Stock Exchange) selama priode 2011-2017 sebesar 100 persen".

Pengaruh profitabilitas, ukuran perusahaan, kebijakan hutang, terhadap variabel dependen nilai perusahaan yang diproksikan dengan price book vakue (PBV) Pengujian Common Effect Model, Fixed Effect Model dan Random Effect Model.

Setelah dilakukan pengujian pada ketiga model di atas, perbandingan pengujiannya disajikan sebagai berikut:

Hasil pengujian model 


\begin{tabular}{llll}
\hline No. & Model & \multicolumn{1}{c}{ Pengujian } & Hasil \\
\hline 1. & Chow Test & Common Effect vs Fixed Effect & Fixed Effect \\
2. & Hausmant Test & Random Effect vs Fixed Effect & Fixed Effect \\
3. & LM Test & Common Effect vs Random Effect & Random Effect \\
\hline
\end{tabular}

Berdasarkan pengujian diatas, maka model yang dipilih untuk mengestimasi model regresi data panel.dalam penelitian ini adalah Fixed Effect Model

Berikut ini peneliti menyajikan Fixed Effect Model

\begin{tabular}{|c|c|c|c|c|c|}
\hline Variable & Coefficient & Std. Error & \multicolumn{2}{|c|}{ t-Statistic } & Prob. \\
\hline DER & 1.573675 & 3.318664 & \multicolumn{2}{|c|}{0.474189} & 0.6414 \\
\hline ROA & 7.458360 & 15.33938 & \multicolumn{2}{|c|}{0.486223} & 0.0330 \\
\hline SIZE & 0.199741 & 0.995967 & \multicolumn{2}{|c|}{0.200549} & 0.8434 \\
\hline $\mathrm{C}$ & 2.917345 & 22.90681 & \multicolumn{2}{|c|}{0.127357} & 0.9002 \\
\hline \multicolumn{6}{|c|}{ Effects Specification } \\
\hline \multicolumn{6}{|c|}{ Cross-section fixed (dummy variables) } \\
\hline R-squared & 0.964427 & \multicolumn{3}{|c|}{ Mean dependent var } & 9.594400 \\
\hline Adjusted R-squared & 0.949779 & \multicolumn{3}{|c|}{ S.D. dependent var } & 15.97310 \\
\hline S.E. of regression & 3.579565 & \multirow{2}{*}{\multicolumn{3}{|c|}{$\begin{array}{l}\text { Akaike info criterion } \\
\text { Schwarz criterion }\end{array}$}} & 5.642697 \\
\hline Sum squared resid & 217.8258 & & & & 6.032737 \\
\hline Log likelihood & -62.53371 & \multicolumn{3}{|c|}{ Hannan-Quinn criter. } & 5.750878 \\
\hline F-statistic & 65.84164 & \multirow{2}{*}{\multicolumn{3}{|c|}{ Durbin-Watson stat }} & 1.033389 \\
\hline Prob(F-statistic) & 0.000000 & & & & \\
\hline \multicolumn{6}{|l|}{ Kesimpulan hasil } \\
\hline Model & $\begin{array}{l}\text { Adjusted R- } \\
\text { squared }\end{array}$ & \multicolumn{2}{|c|}{$\begin{array}{l}\text { Prob.(F-statistic) } \\
\alpha-0,05\end{array}$} & \multicolumn{2}{|c|}{ Probabilitas $\alpha-0,05$} \\
\hline \multirow[t]{3}{*}{ Fixed Effect } & 0.964427 & \multirow[t]{3}{*}{0.0000} & DER & & k Signifikan \\
\hline & & & SIZE & & k Signifikan \\
\hline & & & ROA & & nifikan \\
\hline
\end{tabular}

Uji $F$ menunjukan bahwa "seluruh variabel bebas yang digunakan penelitian ini secara bersama sama mepengaruhi nilai perusahaan (Price Book Value) yang diproksikan dengan PBV perusahaan secara signifikan dengan tingkat keyakinan 100 persen. Sementara pengujian goodnes of fit, menunjukan kefiseien dereminasi $R^{2}=1.00000$ yang berarti seluruh variable bebas profitabilitas, ukuran perusahaan,kebijakan hutang/leverage dapat menjelaskan kepemilikan nilai perusahaan (Price Book Value) 100 persen, sementara sisanya 0 persen dijelaskan oleh faktor-faktor lain yang tidak diikutsertaskan dalam model ini. Sementara nilai koefisien determinasi yang disesuaikan $R^{2}=1,0000$ yang berarti setelah mempertimbangkan derajat kebebasan (degree of freedom), seluruh variabel bebas yang digunakan dalam penelitian ini mampu menjelaskan variasi yang terjadi dalam nilai perusahaan (Price Book Value) perusahaan cosmetics and household yang tercatat di IDX (Indonesia Stock Exchange) selama priode 2011-2017 sebesar 100 persen". (Sunardi N. 2017)

\section{E. KESIMPULAN}

\section{Kesimpulan}

1. Profitabilitas yang di proksikan dengan return on asset (ROA) berpengaruh negatif atau positif signifikan terhadap Leverage yang diproksikan dengan debt equity rasio (DER). 
2. Ukuran Perusahaan yang diproksikan dengan firm size (size) berpengaruh positif atau signifikan terhadap Leverage yang diproksikan dengan debt equity rasio (DER).

3. Profitabilitas yang di proksikan dengan return on asset (ROA) berpengaruh positif atau signifikan terhadap Ukuran Perusahaan firm size (size).

4. Profitabilitas yang di proksikan dengan return on asset $(\mathrm{ROA})$ dan Ukuran Perusahaan yang diproksikan dengan firm size (size) berpengaruh positif atau signifikan terhadap Leverage yang diproksikan dengan debt equity rasio (DER).

5. Profitabilitas yang di proksikan dengan return on asset (ROA) berpengaruh negatif dan positif tidak signifikan terhadap Nilai Perusahaan yang diproksikan dengan price book value (PBV).

6. Ukuran Perusahaan yang diproksikan dengan firm size (size) berpengaruh negatif dan positif tidak signifikan terhadap Nilai Perusahaan diproksikan dengan price book value (PBV).

7. Leverage yang diproksikan dengan debt equity rasio (DER) berpengaruh negatif atau positif tidak signifikan terhadap Nilai Perusahaan yang diproksikan dengan price book value (PBV).

8. Profitabilitas yang di proksikan dengan return on asset (ROA), Ukuran Perusahaan yang diproksikan dengan firm size (size), Leverage yang diproksikan dengan debt equity rasio (DER), berpengaruh negatif atau positif tidak signifikan terhadap Nilai Perusahaan yang diproksikan dengan price book value (PBV).

\section{DAFTAR PUSTAKA}

Dewayanto, T. (2010). The Effect Mechanism Good Corporate Governance on the Performance National Banking Study on banking company are listed in Indonesia Stock Exchange in the period 2006-2008. Fokus Ekonomi, 104 - 123.

Altman, E. I. (1968). Financial Ratios, Discriminant Analysis and the Prediction of Corporate.

Bambang Juanda, J. (2012). Ekonometrika Deret \& Waktu, Teori \& Aplikasi. Bogor:: Penerbit IPB Press PT.

Brigham, E., \& Houston, J. (2013). "Dasar-Dasar Manajemen Keuangan" di terjemahkan oleh Ali Akbar Yulianto. Jakarta: PT. Salemba Empat.

Bukhori, I., \& Raharja. (2012). Pengaruh good corporate governance dan ukuran perusahaan terhadap Kinerja Perusahaan. Diponogoro Journal of Accounting, 1-12.

Dewi Utari, P. A. (2014). Manajemen Keuangan; Kajian Praktik dan Teori dalam Mengelola Keuangan Organisasi Perusahaan. Jakata: Mitra Wacana Media.

Eisenhardt, K. (1989). Agency Theory: An Assessment and Review. Academy of Management Review, Vol. 14, No. 1, 57-74.

Fahmi, I. (2011). Analisis Laporan Keuangan. Bandung:: Alfabeta.

Fama, E. F. (1970). Efficient Capital Markets: A Review of Theory and Empirical Work. The Journal of Finance, 25(Efficient Capital Markets), 28-30.

Foster, G. (1986). Financial Statement Analysis. USA: 2nd ed. Prentice Hall Int.Inc.

Guitman LJ, Z. C. (2012). Principles of Managerial Financial Global Edition 13th Edition. England:: Person Education Limited 2012.

Hanafi, M. (2014). Manajemen Keuangan. Yogyakarta: BPFE Cetakan ke-7.

Hanafi, M., \& A. Halim. (2005). Analisis Laporan Keuangan. Yogyakarta: AMP-YKPN.

Helda E.Erdiana, W. M. (2010). Analisis pengaruh firm size, business risk, profitability, asses growh dan sales growt terhadap struktur modal/leverage perusahaan real estate and property yang terdaftar di BEI Periode 2005-2008 . Jurnal IImiah Universitas Diponegoro, 1 (struktur modal).

Hermuningsih, D. K. (2011). Pengaruh struktur kepemilikan terhadap nilai perusahaan dengan kinerja keuangan dan kebijakan hutang sebagai variabel intervening. Jurnal Siasat Bisnis, 15(manajemen keuangan), 27-36. 
Hossain, H. \&. (2014). Impact of capital stucture policy on value of the firm. Ecoforum, 3(2 $(5))$.

Houston, B. \&. (2013). Essential of Financial Management. Original edition first published by Cengage Learning 2007,Diterjemahkan oleh: Ali Akbar Yulianto. 2011. Dasardasar Manajemen Keuangan. Buku 1-2. Jakarta:: Jakarta::

Hussain Muhammad, B. S. (2014). The Impact of Capital Structure on Firm Performance: Evidence from Pakistan. Journal of Industrial Distribution \& Business, 5(Capital Structure), 13-20.

Jensen, M., \& Meckling, W. (1976). Theory of The Firm: Managerial Behaviour,Agency Cost and Ownership Structure. Journal of Financial Economics 3, 305-360.

Kadim, A., \& Sunardi, N. (2018). Analisis altman z-score untuk memprediksi kebangkrutan pada Bank Pemerintah (BUMN) di Indonesia Tahun 2012-2016. Jurnal Sekuritas, Vol.1, No.3, Maret 2018, 142 - 156.

Kadim, A., \& Sunardi, N. (2018). Pengaruh analisa kesahatan dan kebangkrutan dengan pendekatan altman z-score terhadap harga saham Industri Konstruksi di indonesia yang listing di BEI periode 2013-2017. Jurnal Sekuritas, Vol.1, No.4, Juni 2018, $52-$ 65.

Kasmir. (2014). Analisis Laporan Keuangan. Jakarta: PT. Raja Grafindo Persada.

Kasmir. (2014). Bank dan Lembaga Keuangan Lainnya . Jakarta: PT. Raja Grafindo Persada.

Keown AJ, M. J. (2010). Financial Management: Priciples and Applications 10th Edition. Diterjemahkan oleh: Marcus Priminto Widodo, M.A. 2010.Manajemen Keuangan; Prinsip dan Penerapan. Jakarta: PT Indeks.

Limakrisna, S. d. (2013). Petunjuk praktis penelitian ilmiah untuk menyususn skripsi, tesis, dan disertasi. Jakarta: Penerbit mitra wacana media,2013.

Majluf, M. \&. (1984). Pecking order theory, Corporate Financing and Investment Decisions When Firms Have Information That Investors Do Not Have. Journal of Financial Economics, 13(Pecking order theory), 187-221.

Masril. (2018). LDR, NPL, dan harga saham yang mempengaruhi terhadap ROA dengan jumlah asset sebagai moderating pada perbankan di BEI. AJIE - Asian Journal of Innovation and Entrepreneurship, 107-115.

Nardi Sunardi, A. A. (2018). Determinant Of Cost Efficiency And It's Implications For Companies Performance Incorporated In The Lq.45 Index Listing In Idx For The Period of 2011-2016,. International Journal of Applied Business and Economic Research, 16(Companies Performance).

Nardi Sunardi, E. A. (2018). Effects Of The Bank Soundness With The Rbbr Approach (Risk Base Bank Rating) Of Cost Efficiency And Its Implications On Sharia Bank Performance In Indonesia For The Period Of 2012 - 2016,. International Journal of Economic Research, 15(Bank Soundness).

Nazir, A. K. (2014). Capital Structure and Firm Value: Empirical Capital Structure and Firm Value: Empirical. Capital Structure and Firm Value: Empirical, 1(Firm Value), 11-12.

Nazir, m. (2012). Metode Penelitian. Bogor: Penerbit Gralia indonesia.

Nguyen, T. N.-C. (2015). Capital Structure and Firms' Performance: Evidence from Vietnam's Stock Exchange. International Journal of Economics and Finance, 7(Capital Structure).

Pujiastuti, S. H. (2015). Dasar-dasar Manajemen Keuangan. Yogyakarta: UPP STIM TKPN, Yogyakarta.

Suburmayam KR, W. J. (2014). Financial Statetment Analysis 10th Edition.Diterjemahkan oleh: Dewi Yanti. 2014. Analisis Laporan Keuangan. Jakarta:: Salemba Empat.

Sugiyono. (2012). Metodologi Penelitian Kuantitatif Kualitaif dan $R$ \& D. Bandung: CV. Alfabeta . 
Sunardi, L. H. (2017). determinant of leverage and it's implication on company value of real estate and property sector listing in IDX period of 2011-2015. Man In India, 97(Financial Management), 131-148.

Sunardi, N. (2017). Determinan Kebijakan Utang serta Implikasinya Terhadap Perusahaan (Perusahaan yang tergabung dalam indeks LQ.45 yang terdaftar di BursaEfek Indonesia Tahun 2011- 2015). Jurnal Sekuritas, 78-97.

Sunardi, N. (2018). Determinant of cost efficiency and it's implications for companies performance incorporated in the LQ.45 Index Listing in IDX the Priod of 2011-2016. International Journal of Applied Business and Economic Reserch, 16(Companies Performance), 17-28.

Sunardi, N. (2018). Relevansi Struktur Kepemilikan Tentang Profitabilitas dan Nilai Perusahaan (Studi pada Industri Manufaktur yang terdaftar di Bursa Efek Indonesia Periode 2010-2017). PROCEEDINGS (Vol. 1, No. 1).

Sunardi, N. (2019). Mekanisme Good Corporate Governance Terhadap Nilai Perusahaan Dengan Leverage Sebagai Variabel Intervening Pada Perusahaan Manufaktur Yang Terdaftar Di Bursa Efek Indonesia Tahun 2012-2018. JIMF (Jurnal IImiah Manajemen Forkamma), Vol.2, No.2 , Juli 2019, 48 - 61.

Sunardi, N., \& Permana, D. I. ( 2019 ). Faktor-Faktor Yang Mempengaruhi Harga Saham Dan Dampaknya Pada Nilai Perusahaan. JIMF (Jurnal IImiah Manajemen Forkamma), 62-72.

Wiranata, Y. A., \& Nugrahanti, Y. W. (2013). Pengaruh Struktur Kepemilikan Terhadap Profitabilitas Perusahaan Manufaktur di Indonesia. Jurnal Akuntansi dan Keuangan, Vol. 15, No. 1, 15-26.

Wulandari, F., Burhanudin, \& Widayanti, R. (2017). Analisis prediksi kebangkrutan menggunakan metode altman (z-score) pada perusahaan farmasi (studi kasus pada perusahaan yang terdaftar di bursa efek indonesia tahun 2011-2015). BENEFIT Jurnal Manajemen dan Bisnis, 15-27. 